\title{
Revisiting the Kinetics and Mechanism of Bromate-Bromide Reaction
}

\author{
Carlos Eduardo S. Côrtes ${ }^{a}$ and Roberto B. Faria ${ }^{b^{*}}$

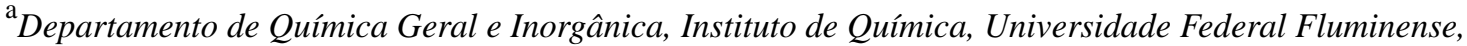 \\ Morro do Valonguinho s/n, 24210-150, Niterói - RJ, Brazil \\ ${ }^{\mathrm{b}}$ Departamento de Química Inorgânica, Instituto de Química, Universidade Federal do Rio de Janeiro, \\ CP 68563, 21945-970, Rio de Janeiro - RJ, Brazil
}

\begin{abstract}
A reação bromato-brometo, em meio de ácido perclórico, foi observada numa faixa de acidez até então não estudada. A reação foi acompanhada através da medida da absorvância no ponto isosbéstico para as espécies $\mathrm{Br}_{2}$ e $\mathrm{Br}_{3}{ }^{-}(\lambda=446 \mathrm{~nm})$. Observou-se um comportamento de primeira ordem para o bromato e para o brometo e um comportamento de segunda ordem para $\mathrm{o}^{+}$, levando à lei de velocidade $\mathrm{v}=k\left[\mathrm{BrO}_{3}{ }^{-}\right]\left[\mathrm{Br}^{-}\right]\left[\mathrm{H}^{+}\right]^{2}$. Esta lei de velocidade sugere um mecanismo envolvendo duas protonações sucessivas do íon bromato, formando $\mathrm{o}_{2} \mathrm{BrO}_{3}{ }^{+}$, que então reage com o íon brometo.Estes resultados discordam de outros estudos que verificaram um comportamento de segunda ordem para o íon brometo, bem como um comportamento de primeira ordem para o $\mathrm{H}^{+}$, que levaram a propor a existência de intermediários tais como $\mathrm{H}_{2} \mathrm{Br}_{2} \mathrm{O}_{3}$ e $\mathrm{HBr}_{2} \mathrm{O}_{3}{ }^{-}$. O comportamento de segunda ordem observado para o $\mathrm{H}^{+}$na faixa de concentração $0,005 \leq\left[\mathrm{H}^{+}\right] \leq 2,77 \mathrm{~mol} \mathrm{~L}^{-1}$ permite afirmar que o $\mathrm{p} K_{\mathrm{a}}$ do ácido brômico, $\mathrm{HBrO}_{3}$, deve ser menor do que $-0,5$ a $25^{\circ} \mathrm{C}$, diferentemente de todas as propostas existentes até agora na literatura para o valor deste $\mathrm{p} K_{\mathrm{a}}$.

The bromate-bromide reaction was investigated in an acidity range not studied yet. The reaction was followed at the $\mathrm{Br}_{2} / \mathrm{Br}_{3}{ }^{-}$isosbestic point $(\lambda=446 \mathrm{~nm})$. It was observed a first-order behavior for bromate and bromide ions and a second-order behavior for $\mathrm{H}^{+}$ion that results in the rate law $v=k\left[\mathrm{BrO}_{3}^{-}\right]\left[\mathrm{Br}^{-}\right]\left[\mathrm{H}^{+}\right]^{2}$. This rate law suggests a mechanism involving two successive protonation of bromate followed by the interaction of the intermediate species $\mathrm{H}_{2} \mathrm{BrO}_{3}{ }^{+}$with bromide. These results disagree with the obtained by other authors who observed a second-order behavior for the bromide and first-order for $\mathrm{H}^{+}$, and have proposed intermediate species like $\mathrm{H}_{2} \mathrm{Br}_{2} \mathrm{O}_{3}$ and $\mathrm{HBr}_{2} \mathrm{O}_{3}^{-}$. The second-order for $\left[\mathrm{H}^{+}\right]$observed in the range $0.005 \leq\left[\mathrm{H}^{+}\right] \leq 2.77 \mathrm{~mol} \mathrm{~L}^{-1}$ sets down that the $\mathrm{p} K_{\mathrm{a}}$ of bromic acid, $\mathrm{HBrO}_{3}$, must be lower than $-0.5\left(T=25^{\circ} \mathrm{C}\right)$, different from all other values for this $\mathrm{p} K_{\mathrm{a}}$ proposed in the literature.
\end{abstract}

Keywords: bromic acid, $\mathrm{p} K_{\mathrm{a}}$, bromate, bromide, kinetics

\section{Introducion}

Judson and Walker ${ }^{1}$ were the first to study the reaction between bromate and bromide (equation 1) and concluded that it follows a fourth-order rate law (equation 2).

$$
\begin{aligned}
& \mathrm{BrO}_{3}{ }^{-}+5 \mathrm{Br}^{-}+6 \mathrm{H}^{+} \rightarrow 3 \mathrm{Br}_{2}+3 \mathrm{H}_{2} \mathrm{O} \\
& -d\left[\mathrm{BrO}_{3}^{-}\right] / d t=k\left[\mathrm{BrO}_{3}^{-}\right]\left[\mathrm{Br}^{-}\right]\left[\mathrm{H}^{+}\right]^{2}
\end{aligned}
$$

This rate law was confirmed by several authors ${ }^{2-8}$ which observed that the rate constant decreases with the increase of the ionic strength, $I$, for $I \leq 1 \mathrm{~mol} \mathrm{~L}^{-1}$ and increases with the

*e-mail: faria@iq.ufrj.br increase of $I$ for $I>1 \mathrm{~mol} \mathrm{~L}^{-1}$. In addition, the possibility of a fifth-order rate law at high ionic strength with second-order on bromide was pointed out by some authors ${ }^{5}$.

Rábai et al. ${ }^{9}$ were the first to use ultraviolet spectroscopy to follow this reaction at the $\mathrm{Br}_{2} / \mathrm{Br}_{3}{ }^{-}$isosbestic point. They measured the initial rate for a wide range of bromide concentration $\left(0.1<\left[\mathrm{Br}^{-}\right]<2.0 \mathrm{~mol} \mathrm{~L}^{-1}\right)$ at low concentrations of $\mathrm{H}^{+}$and bromate. To explain the observed behavior, especially at high $\left[\mathrm{Br}^{-}\right]$, they proposed a rate law with three terms, as indicated in equation 3 , and a mechanism with six elementary steps including the intermediate species $\mathrm{H}_{2} \mathrm{BrO}_{3}{ }^{+}, \mathrm{HBr}_{2} \mathrm{O}_{3}^{-}$and $\mathrm{H}_{2} \mathrm{Br}_{2} \mathrm{O}_{3}$.

$$
\begin{aligned}
& -d\left[\mathrm{BrO}_{3}^{-}\right] / d t=k^{\prime}\left[\mathrm{BrO}_{3}^{-}\right]\left[\mathrm{Br}^{-}\right]\left[\mathrm{H}^{+}\right]^{2}+ \\
& +k^{\prime \prime}\left[\mathrm{BrO}_{3}^{-}\right]\left[\mathrm{Br}^{-}\right]^{2}\left[\mathrm{H}^{+}\right]+k^{\prime \prime \prime}\left[\mathrm{BrO}_{3}^{-}\right]\left[\mathrm{Br}^{-}\right]^{2}\left[\mathrm{H}^{+}\right]^{2}
\end{aligned}
$$


Burgos et. al. ${ }^{10}$ followed this reaction at the $\lambda_{\text {max }}$ of $\mathrm{Br}_{2}$, using UV-Vis spectroscopy. They found a significant increase in the rate constant of this reaction at high values of ionic strength especially when it was controlled by $\mathrm{NaClO}_{4}$. Domínguez et al. ${ }^{8}$ have followed this reaction at the $\lambda_{\max }$ of $\mathrm{Br}_{3}{ }^{-}$in a wide range of ionic strengths. They found a decrease, followed by an increase in the rate constant with the increase of the ionic strength.

In this work we extend the $\left[\mathrm{H}^{+}\right]$to the high acidity range of 0.005 to $2.77 \mathrm{~mol} \mathrm{~L}^{-1}$, at low concentrations of bromate and bromide. The obtained kinetic results posed some questions to the rate law proposed by Rabay et al. ${ }^{9}$ and allowed us to establish that the $\mathrm{p} K_{\mathrm{a}}$ of $\mathrm{HBrO}_{3}$ must be lower than -0.5 .

\section{Experimental Section}

Analytical grade chemicals $\mathrm{NaBrO}_{3}$ (Riedel-deHaën), $\mathrm{HClO}_{4}$ (Merck), $\mathrm{NaClO}_{4}$ (Riedel-deHaën; Vetec), and $\mathrm{NaBr}$ (Grupo Química) were used without further purification. Water used had $18 \mathrm{M} \Omega$ resistivity and was obtained by a Milli-Q Plus purification system.

Kinetics experiments were carried out by two methods. The first method (to be assumed when not indicated) employed the UV-Vis diode array spectrophotometer HP 8452-A and Suprasil standard quartz cuvette with $1.00 \mathrm{~cm}$ optical path (Hellma 110-QS). After the reagents were transferred to the cuvette using a fast delivering digital pipette (Transferpette), the cuvette was closed tightly with a round Teflon plug. The total volume of the solution in the cuvette was $2.0-3.0 \mathrm{~mL}$. The cuvette containing a $3 \times 5$ $\mathrm{mm}$ Teflon coated cylindrical stirring-bar was placed inside a jacketed cuvette holder equipped with a water powered magnetic stirrer. The stirring rate was about $900 \mathrm{rpm}$ and no vortices were observed inside the cuvette. Experimental points were taken at each $0.1 \mathrm{~s}$ for the faster experiments. The estimated dead time after mixing the reagents was about 2 s. The second method was the stopped-flow technique performed by the use of the Hi-Tech Dual Mixing Microvolume Stopped-Flow SF-61DX2. For both methods the temperature was maintained at $25.0 \pm 0.1{ }^{\circ} \mathrm{C}$ by a circulating bath and the ionic strength of all solutions was adjusted with $\mathrm{NaClO}_{4}$.

The reaction was followed at $\lambda=446 \mathrm{~nm}$ that corresponds to the isosbestic point of the mixture of $\mathrm{Br}_{2}$ and $\mathrm{Br}_{3}{ }^{-}\left(\varepsilon=111 \mathrm{~L} \mathrm{~mol}^{-1} \mathrm{~cm}^{-1}\right)$. The extinction coefficient at the isosbestic point was obtained by fitting a second degree polynomial to the experimental absorbance data for $\mathrm{Br}_{2}$ and $\mathrm{Br}_{3}{ }^{-}$obtained by Raphael in $2 \mathrm{~mol} \mathrm{~L}^{-1}$ perchloric acid solution ${ }^{11}$. Our value for the extinction coefficient ( $\varepsilon=111 \mathrm{~L} \mathrm{~mol}^{-1} \mathrm{~cm}^{-1}$ ) of the isosbestic point of $\mathrm{Br}_{2}$ and $\mathrm{Br}_{3}{ }^{-}$is in the middle of the values found by Lengyel $e t$. al. ${ }^{12}\left(\varepsilon=130 \mathrm{~L} \mathrm{~mol}^{-1} \mathrm{~cm}^{-1}, \lambda=441 \mathrm{~nm}\right.$, in perchloric acid solution) and Rábai et al..$^{9}\left(\varepsilon=83 \mathrm{~L} \mathrm{~mol}^{-1} \mathrm{~cm}^{-1} ; \lambda=544 \mathrm{~nm}\right.$ cannot be right because bromine solutions do not absorb at this wavelength ${ }^{13}$ ).

In the case of HP results the initial rate of reaction, $v_{0}$, was determined by fitting a second degree polynomial, $a t^{2}$ $+b t+c$, to the total bromine concentration versus time curve. The coefficient $b$ is the initial rate. In the case of stopped-flow experiments, $v_{0}$ was determined by linear regression fitting to the initial time experimental data. All experimental kinetic data presented here are the average of a minimum of five determinations.

Data treatment and curve fitting for kinetic data were carried out by using the LOTUS $1-2-3^{14}$.

\section{Results and Discussion}

Table 1 presents the first-order rate constants obtained at different bromide concentrations, keeping constant the initial bromate concentration, acid concentration and ionic strength. Since the bromide and acid concentration are both much higher than bromate concentration, a pseudo-firstorder condition is satisfied and pseudo-first-order rate constants could be obtained from plots of $\log \left(\mathrm{A}_{\mathrm{t}+\Delta \mathrm{t}}-\mathrm{A}_{\mathrm{t}}\right)$ $\times \mathrm{t}$ (Guggenheim method) ${ }^{15}$. These plots have shown excellent linear behavior, confirming the first-order for bromate. The plot $\log k_{\text {obs }} \times \log \left[\mathrm{Br}^{-}\right]_{0}$ produced a good straight line $\left(\mathrm{R}^{2}=0.998\right)$ with slope $0.984 \pm 0.022$, indicating a first-order behavior for the bromide too.

Table 1. First-order rate constants for the determination of the bromide order. Constrains: $\left[\mathrm{BrO}_{3}^{-}\right]_{0}=1.00 \times 10^{-3} \mathrm{~mol} \mathrm{~L}^{-1} ;\left[\mathrm{HClO}_{4}\right]_{0}=0.1137$ mol L-1 $;=0.55 \mathrm{~mol} \mathrm{~L}^{-1}$ (adjusted with $\mathrm{NaClO}_{4}$ ); $T=25.0^{\circ} \mathrm{C}$.

\begin{tabular}{cc}
\hline$\left[\mathrm{Br}^{-}\right]_{0} / \mathrm{mol} \mathrm{L}^{-1}$ & $k_{\mathrm{obs}} / 10^{-3} \mathrm{~s}^{-1}$ \\
\hline 0.400 & 14.36 \\
0.200 & 7.213 \\
0.100 & 3.802 \\
0.0800 & 2.816 \\
0.0600 & 2.250 \\
\hline
\end{tabular}

Table 2 presents the initial rate values for a wide range of $\left[\mathrm{H}^{+}\right]$. The initial bromate and bromide concentrations were adjusted to allow a convenient time scale to follow the reaction.

Plots of $\log \mathrm{v}_{0} \times \mathrm{p}[\mathrm{H}]$, where $\mathrm{p}[\mathrm{H}]=-\log \left[\mathrm{H}^{+}\right]$, from data in Table 2 (which is equivalent to a $\mathrm{pH}$-rate profile ${ }^{16}$, plot of $\left.\log \mathrm{k}_{\mathrm{obs}} \times \mathrm{p}[\mathrm{H}]\right)$ present slopes very close to -2 for all four sets of experiments (see Table 3 ). These results point out the second-order in $\left[\mathrm{H}^{+}\right]$as stated by equation 2 . Dividing $v_{0}$ by the initial concentrations of bromate and bromide it is possible to put all experimental data in the same plot, as shown in Figure 1. 
Table 2. Initial rate values at $25.0^{\circ} \mathrm{C}$.

\begin{tabular}{|c|c|c|c|c|}
\hline $\begin{array}{l}{\left[\mathrm{BrO}_{3}^{-}\right]_{0} /} \\
\mathrm{mol} \mathrm{L}^{-1}\end{array}$ & $\begin{array}{l}{\left[\mathrm{Br}^{-}\right]_{0} /} \\
\mathrm{mol} \mathrm{L}^{-1}\end{array}$ & $\begin{array}{c}I / \\
\text { mol L-1 }\end{array}$ & $\begin{array}{c}{\left[\mathrm{H}^{+}\right]_{0}{ }^{(\mathrm{a})}} \\
\mathrm{mol} \mathrm{L}^{-1}\end{array}$ & $\begin{array}{c}\mathrm{v}_{0} / \\
\left(10^{-6} \mathrm{~mol} \mathrm{~L}^{-1} \mathrm{~s}^{-1}\right)\end{array}$ \\
\hline $1.00 \times 10^{-3}$ & $1.00 \times 10^{-1}$ & 0.201 & $\begin{array}{l}0.00500 \\
0.0100 \\
0.0150 \\
0.0250 \\
0.0500 \\
0.0750 \\
0.100\end{array}$ & $\begin{array}{l}0.00467 \\
0.0179 \\
0.0470 \\
0.112 \\
0.473 \\
1.07 \\
2.13\end{array}$ \\
\hline $7.00 \times 10^{-4}$ & $5.00 \times 10^{-2}$ & 1.05 & $\begin{array}{l}0.0361 \\
0.0516 \\
0.0734 \\
0.0988 \\
0.148 \\
0.197 \\
0.247 \\
0.296 \\
0.347 \\
0.572\end{array}$ & $\begin{array}{c}0.107 \\
0.242 \\
0.513 \\
0.917 \\
2.60 \\
4.13 \\
6.90 \\
9.00 \\
10.1 \\
26.0\end{array}$ \\
\hline $2.00 \times 10^{-4}$ & $1.00 \times 10^{-3}$ & 3.50 & $\begin{array}{l}1.032 \\
1.296 \\
1.552 \\
1.772 \\
2.004 \\
2.406 \\
2.772\end{array}$ & $\begin{array}{l}0.760 \\
1.37 \\
1.99 \\
2.98 \\
3.60 \\
4.53 \\
5.53\end{array}$ \\
\hline $7.00 \times 10^{-4}$ & $5.00 \times 10^{-2}$ & 1.05 & $\begin{array}{l}0.105 \\
0.200 \\
0.301 \\
0.409 \\
0.500 \\
0.600 \\
0.691 \\
0.800 \\
0.900 \\
1.03\end{array}$ & $\begin{array}{c}1.32^{(\mathrm{b})} \\
4.49^{(\mathrm{b})} \\
9.53^{(\mathrm{b})} \\
16.6^{(\mathrm{b})} \\
27.8^{(\mathrm{b})} \\
41.6^{(\mathrm{b})} \\
55.3^{(\mathrm{b})} \\
75.5^{(\mathrm{b})} \\
98.0^{(\mathrm{b})} \\
124^{(\mathrm{b})}\end{array}$ \\
\hline
\end{tabular}

(a) adjusted using $\mathrm{HClO}_{4}$; (b) stopped-flow results

Table 3. Slope of the linear fitting for the plots of $\log \mathrm{v}_{\mathrm{o}} \times \mathrm{p}[\mathrm{H}]$. $\left(T=25.0^{\circ} \mathrm{C}\right)$.

\begin{tabular}{ccccc}
\hline $\begin{array}{c}\left.\mathrm{BrO}_{3}{ }^{-}\right]_{0} / \\
\mathrm{mol} \mathrm{L}^{-1}\end{array}$ & $\begin{array}{c}{\left[\mathrm{Br}^{-}\right]_{0} /} \\
\mathrm{mol} \mathrm{L}\end{array}$ & $\begin{array}{c}\text { II } \\
\mathrm{mol} \mathrm{L}^{-1}\end{array}$ & $\begin{array}{c}{\left[\mathrm{H}^{+}\right]_{0} /} \\
\mathrm{mol} \mathrm{L}^{-1}(\mathrm{a})\end{array}$ & $\begin{array}{c}\text { Slope log } \\
\mathrm{v}_{0} \times \mathrm{p}[\mathrm{H}]\end{array}$ \\
\hline $1.00 \times 10^{-3}$ & $1.00 \times 10^{-1}$ & 0.201 & $0.00500-0.100$ & $-2.03 \pm 0.03$ \\
$7.00 \times 10^{-4}$ & $5.00 \times 10^{-2}$ & 1.05 & $0.0361-0.572$ & $-2.01 \pm 0.06$ \\
$2.00 \times 10^{-4}$ & $1.00 \times 10^{-3}$ & 3.50 & $1.032-2.772$ & $-2.02 \pm 0.14$ \\
$7.00 \times 10^{-4}$ & $5.00 \times 10^{-2}$ & 1.05 & $0.105-1.03$ & $-2.02 \pm 0.03^{(\mathrm{b})}$ \\
\hline
\end{tabular}

(a) adjusted using $\mathrm{HClO}_{4 \text {; }}$ (b) stopped-flow results

Considering the mechanism below (equations 4 to 6 ) the reactive species against bromide is $\mathrm{H}_{2} \mathrm{BrO}_{3}{ }^{+}$.

$$
\begin{aligned}
& \mathrm{H}_{2} \mathrm{BrO}_{3} \stackrel{+}{\underset{k_{-1}}{\rightleftharpoons}} \mathrm{H}^{+}+\mathrm{HBrO}_{3} \\
& \mathrm{HBrO}_{3} \underset{k_{-2}}{\stackrel{k_{2}}{\rightleftharpoons}} \mathrm{H}^{+}+\mathrm{BrO}_{3}^{-} \\
& \mathrm{H}_{2} \mathrm{BrO}_{3}{ }^{+}+\mathrm{Br}^{-} \stackrel{k_{3}}{\longrightarrow} \text { products }
\end{aligned}
$$

Using this scheme and considering that the ratedetermining step is reaction 6 , the rate of reaction, $v$, can be given as a function of the total bromine $(\mathrm{V})$ concentration.

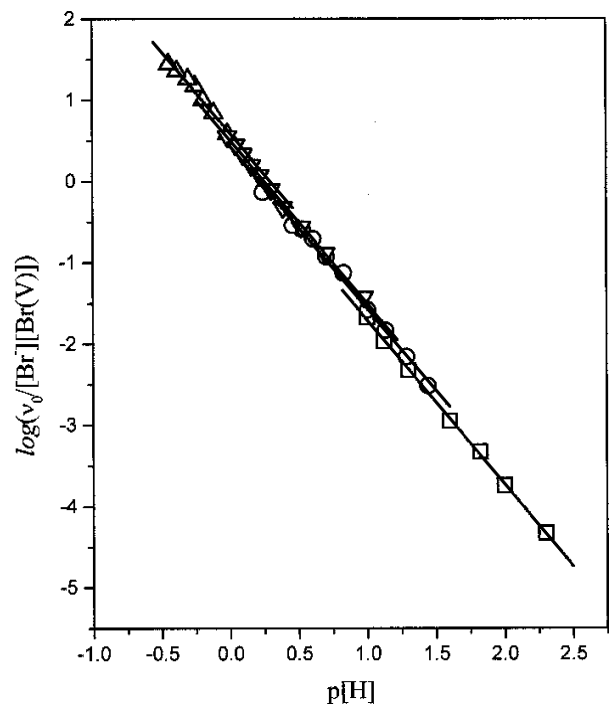

Figure 1.pH-rate profile of Table 2 data as a plot of $\log \left(\mathrm{v}_{0} /\left[\mathrm{Br}^{-}\right]_{0}[\mathrm{Br}(\mathrm{V})]_{0}\right)$ $\times \mathrm{p}[\mathrm{H}] .(\square)\left[\mathrm{BrO}_{3}^{-}\right]_{0}=1.00 \times 10^{-3} \mathrm{~mol} \mathrm{~L}^{-1},\left[\mathrm{Br}^{-}\right]_{0}=1.00 \times 10^{-1} \mathrm{~mol} \mathrm{~L}^{-1}$, $I=0.201 \mathrm{~mol} \mathrm{~L}^{-1} ;(\mathrm{O})\left[\mathrm{BrO}_{3}^{-}\right]_{0}=7.00 \times 10^{-4} \mathrm{~mol} \mathrm{~L}^{-1},\left[\mathrm{Br}^{-}\right]_{0}=5.00 \times 10^{-2}$ $\mathrm{mol} \mathrm{L}-1, I=1.05 \mathrm{~mol} \mathrm{~L}^{-1} ;(\Delta)\left[\mathrm{BrO}_{3}^{-}\right]_{0}=2.00 \times 10^{-4} \mathrm{~mol} \mathrm{~L}^{-1},\left[\mathrm{Br}^{-}\right]_{0}=$ $1.00 \times 10^{-3} \mathrm{~mol} \mathrm{~L}^{-1}, I=3.50 \mathrm{~mol} \mathrm{~L}^{-1} ;(\nabla)$ same as $(\mathrm{O})$ but using stoppedflow technique. $T=25.0^{\circ} \mathrm{C}$.

$$
\begin{aligned}
& {[\mathrm{Br}(\mathrm{V})]=\left[\mathrm{H}_{2} \mathrm{BrO}_{3}^{+}\right]+\left[\mathrm{HBrO}_{3}\right]+\left[\mathrm{BrO}_{3}^{-}\right]} \\
& {\left[\mathrm{H}_{2} \mathrm{BrO}_{3}^{+}\right]=\frac{[\mathrm{Br}(\mathrm{V})]\left[\mathrm{H}^{+}\right]^{2}}{\left[\mathrm{H}^{+}\right]^{2}+K_{1}\left[\mathrm{H}^{+}\right]+K_{1} K_{2}}} \\
& v=k_{3}\left[\mathrm{H}_{2} \mathrm{BrO}_{3}^{+}\right][\mathrm{Br}] \\
& \mathbf{v}=\frac{k_{3}\left[\mathrm{Br}^{-}\right][\mathrm{Br}(\mathrm{V})]\left[\mathrm{H}^{+}\right]^{2}}{\left[\mathrm{H}^{+}\right]^{2}+K_{1}\left[\mathrm{H}^{+}\right]+K_{1} K_{2}}
\end{aligned}
$$

Where $K_{1}=k_{1} / k_{-1}$ and $K_{2}=k_{2} / k_{-2}$. At very low $\mathrm{H}^{+}$ concentration equation 10 turns into equation 11 that is identical to equation 2 , with the fourth-order rate constant, $k$, equal to $k_{3} / K_{1} K_{2}$.

$\mathbf{v}=\frac{k_{3}\left[\mathrm{Br}^{-}\right][\mathrm{Br}(\mathrm{V})]\left[\mathrm{H}^{+}\right]^{2}}{K_{1} K_{2}}$

Applying logarithm in both sides one gets equations 12 and 13.

$\log v=\log \left\{k_{3}\left[\mathrm{Br}^{-}\right][\mathrm{Br}(\mathrm{V})] / K_{1} K_{2}\right\}+2 \log \left[\mathrm{H}^{+}\right]$

$\log v=\log \left\{k_{3}\left[\mathrm{Br}^{-}\right][\mathrm{Br}(\mathrm{V})] / K_{1} K_{2}\right\}-2 \mathrm{p}[\mathrm{H}]$

In this way, the linear behavior with slope equal -2 observed in Figure 1 and Table 3 indicates that the order with respect to $\mathrm{H}^{+}$is 2 . Most importantly, the $\mathrm{H}^{+}$concentration is indeed very low compared with $K_{1}$ and $K_{2}$, otherwise the approximation that turns equation 10 into equation 11 would not be valid. This indicates that in our reaction medium 
we cannot have any protonation equilibrium involving an acid with $\mathrm{pK}_{\mathrm{a}}$ higher than, approximately, -0.5 and puts an upper limit for the $\mathrm{p} K_{\mathrm{a}}$ of $\mathrm{HBrO}_{3}\left(\mathrm{p} K_{2}\right)$.

Table 4 shows the fourth-order rate constant, $k$, at different ionic strengths together with other authors results. Our $k$ values were calculated using the data in Tables 1 and 2 and based on the rate law given by equation 2 .

Table 4. Selected values of the fourth-order rate constant, $k$, for reaction 1. $T=25.0^{\circ} \mathrm{C}$

\begin{tabular}{|c|c|c|c|}
\hline$I / \mathrm{mol} \mathrm{L}^{-1}$ & $k / \mathrm{L}^{3} \mathrm{~mol}^{-3} \mathrm{~s}^{-1}$ & Main Electrolyte & Ref. \\
\hline 0.106 & 3.59 & $\mathrm{HClO}_{4}, \mathrm{NaClO}_{4}$ & 4 \\
\hline 0.16 & 2.75 & $\mathrm{HBr}, \mathrm{Mg}\left(\mathrm{ClO}_{4}\right)_{2}$ & 5 \\
\hline 0.19 & 1.68 & $\mathrm{H}_{2} \mathrm{SO}_{4}$ & 3 \\
\hline 0.20 & $1.92 \pm 0.12$ & $\mathrm{HClO}_{4}, \mathrm{NaClO}_{4}$ & this work \\
\hline 0.20 & 3.18 & $\mathrm{HClO}_{4}, \mathrm{NaClO}_{4}$ & 4 \\
\hline 0.23 & 3.22 & $\mathrm{HBr}, \mathrm{NaClO}_{4}$ & 8 \\
\hline 0.25 & 2.35 & $\mathrm{HBr}, \mathrm{Mg}\left(\mathrm{ClO}_{4}\right)_{2}$ & 5 \\
\hline 0.25 & 3.0 & $\mathrm{NaClO}_{4}$ & 10 \\
\hline 0.51 & 2.42 & $\mathrm{HClO}_{4}, \mathrm{NaClO}_{4}$ & 4 \\
\hline 0.55 & $2.83 \pm 0.08$ & $\mathrm{HClO}_{4}, \mathrm{NaClO}_{4}$ & this work \\
\hline 0.55 & 2.96 & $\mathrm{HBr}, \mathrm{NaClO}_{4}$ & 8 \\
\hline 0.54 & 1.10 & $\mathrm{H}_{2} \mathrm{SO}_{4}$ & 3 \\
\hline 0.64 & 1.55 & $\mathrm{HBr}, \mathrm{Mg}\left(\mathrm{ClO}_{4}\right)_{2}$ & 5 \\
\hline 0.81 & 1.37 & $\mathrm{HBr}, \mathrm{Mg}\left(\mathrm{ClO}_{4}\right)_{2}$ & 5 \\
\hline 0.81 & 2.4 & $\mathrm{HClO}_{4}, \mathrm{NaClO}_{4}$ & 4 \\
\hline 0.91 & 1.05 & $\mathrm{HBr}$ & 1 \\
\hline 1.0 & 1.18 & $\mathrm{HBr}, \mathrm{Mg}\left(\mathrm{ClO}_{4}\right)_{2}$ & 5 \\
\hline 1.0 & 2.8 & $\mathrm{NaClO}_{4}$ & 10 \\
\hline 1.0 & 2.79 & $\mathrm{HBr}, \mathrm{NaClO}_{4}$ & 8 \\
\hline 1.05 & $2.76 \pm 0.36$ & $\mathrm{HClO}_{4}, \mathrm{NaClO}_{4}$ & this work \\
\hline 1.05 & $3.24 \pm 0.18$ & $\mathrm{HClO}_{4}, \mathrm{NaClO}_{4}$ & this work ${ }^{(a)}$ \\
\hline 3.0 & 38.7 & $\mathrm{NaClO}_{4}$ & 10 \\
\hline 3.0 & $17.9^{(b)}$ & $\mathrm{NaH}_{2} \mathrm{PO}_{4} / \mathrm{H}_{3} \mathrm{PO}_{4}$ buffer & 9 \\
\hline 3.0 & 4.29 & $\mathrm{HBr}, \mathrm{NaClO}_{4}$ & 8 \\
\hline 3.5 & $4.07 \pm 0.40$ & $\mathrm{HClO}_{4}, \mathrm{NaClO}_{4}$ & this work \\
\hline
\end{tabular}

(a) stopped-flow results; (b) recalculated in this work.

Our results do not show any deviation from the first-order for bromide or bromate, in agreement with other authors ${ }^{1-8}$. A closer examination of the data presented by Rábai et al. ${ }^{9}$ show that their results agree with this too. Surprisingly, Rábai et al. alleged that they observed a deviation from the firstorder on bromide when the concentration of this ion was higher than $0.5 \mathrm{~mol} \mathrm{~L}^{-1}$. For this reason they proposed a rate law (equation 3 ) that includes additional terms with second-order on bromide and first-order on $\mathrm{H}^{+}$, when compared with our rate law equation 2 . To explain their rate law Rábai et al. proposed the following mechanism:

$$
\begin{aligned}
& \mathrm{BrO}_{3}^{-}+\mathrm{H}^{+}=\mathrm{HBrO}_{3} \\
& \mathrm{HBrO}_{3}+\mathrm{H}^{+}=\mathrm{H}_{2} \mathrm{BrO}_{3}^{+} \\
& \mathrm{H}_{2} \mathrm{BrO}_{3}^{+}+\mathrm{Br}^{-}=\mathrm{H}_{2} \mathrm{Br}_{2} \mathrm{O}_{3} \rightarrow \text { products } \\
& \mathrm{H}_{2} \mathrm{Br}_{2} \mathrm{O}_{3}+\mathrm{Br}^{-} \rightarrow \text { products } \\
& \mathrm{HBrO}_{3}+\mathrm{Br}^{-}=\mathrm{HBr}_{2} \mathrm{O}_{3}^{-}
\end{aligned}
$$

$\mathrm{HBr}_{2} \mathrm{O}_{3}^{-}+\mathrm{Br}^{-} \rightarrow$ products

Indeed, their results present an order in $\left[\mathrm{H}^{+}\right]$in the range of 1.67 to 1.83 . In this way, their results do not agree with the rate law of equation 3 . Additionally, we were not able to reproduce their calculated results for the initial rate using their rate constants $k^{\prime}=4.37 \mathrm{~L}^{3} \mathrm{~mol}^{-3} \mathrm{~s}^{-1}, k^{\prime \prime}=0.014 \mathrm{~L}^{3} \mathrm{~mol}^{-3} \mathrm{~s}^{-1}$ and $k^{\prime \prime \prime}=0.56 \mathrm{~L}^{4} \mathrm{~mol}^{-4} \mathrm{~s}^{-1}$. From their data we calculated rate constants equal to $k^{\prime}=17.9 \mathrm{~L}^{3} \mathrm{~mol}^{-3} \mathrm{~s}^{-1}$, $k^{\prime \prime}=0.019 \mathrm{~L}^{3} \mathrm{~mol}^{-3} \mathrm{~s}^{-1}$ and $k^{\prime \prime \prime}=2.84 \times 10^{-4} \mathrm{~L}^{4} \mathrm{~mol}^{-4} \mathrm{~s}^{-}$ 1 that are quite different from their values, especially for $k^{\prime}$ and $k^{\prime \prime \prime}$.

On the other hand, we can state that our results support the mechanism represented by equations 4 to 6 that propose that $\mathrm{H}_{2} \mathrm{BrO}_{3}{ }^{+}$is the reactive species to $\mathrm{Br}^{-}$. In addition, our results did not support the proposal of the existence of the intermediates $\mathrm{HBr}_{2} \mathrm{O}_{3}{ }^{-}$and $\mathrm{H}_{2} \mathrm{Br}_{2} \mathrm{O}_{3}$.

As can be seen in Table 4, our values for the fourthorder rate constant are in good agreement with the values obtained by most other authors, especially those of Domínguez and Iglesias ${ }^{8}$. At high $I$ values our results show an increase in the rate constant with the increase of the ionic strength as has been observed by many authors, but not the very strong increase observed by Burgos et al. ${ }^{10}$. We are not able to explain the reason for this disagreement.

Based on the linear behavior shown in the Figure 1 for all sets of experimental data, we concluded that if there is some fast protonation equilibrium (equations 4 and 5) before the determining step, the $\mathrm{p} K_{\mathrm{a}}$ of these acids cannot be in the $\mathrm{p}[\mathrm{H}]$ range investigated in this work $(-0.44<\mathrm{p}[\mathrm{H}]<$ 2.3). This result is in disagreement with the $\mathrm{HBrO}_{3} \mathrm{p} K_{\mathrm{a}}$ values proposed by other authors (see Table 5).

A comparison of the known bromic acid $\mathrm{p} K_{2}$ values (see Table 5) shows that they are very different from each other. We have no indication on how the $\mathrm{p} K_{2}$ value of 0.7 found in the Pourbaix's Atlas ${ }^{17}$ was determined. The other $\mathrm{p} K_{2}$ values of 1.87 and -0.292 were both determined by kinetic experiments and are depend on the proposed mechanism for the reaction. On the other hand, our kinetic results do not allow to determine the $\mathrm{p} K_{2}$ value, but show that all other values in Table 5 are unacceptable. Unfortunately, all attempts we have made to follow this reaction at a still more acid medium did not give us reproducible results, showing that the reaction is too fast to be followed, even by stopped-flow technique.

Table 5. $\mathrm{p} K_{\mathrm{a}}$ values for bromic acid

\begin{tabular}{cll}
\hline $\mathrm{p} K_{2}$ & $T /{ }^{\circ} \mathrm{C}$ & Ref. \\
\hline 0.70 & - & 17 \\
1.87 & 27 & 18 \\
-0.292 & 40 & 19 \\
\hline
\end{tabular}




\section{Acknowledgments}

This work was sponsored by Conselho Nacional de Desenvolvimento Científico e Tecnológico-CNPq, Fundação de Amparo à Pesquisa do Estado do Rio de Janeiro-FAPERJ, Fundação José Bonifácio-FUJB, Financiadora de Estudos e Projetos-FINEP and CEPG-UFRJ.

\section{References}

1. Judson, W.; Walker, J. W. J. Chem. Soc. 1898, 73, 410.

2. Skrabal, A.; Weberitsch, S. R. Monatsh. Chem. 1915, 36, 211.

3. Bray, W. C.; Davis, P. R. J. Am. Chem. Soc. 1930, $52,1427$.

4. Young; H. A.; Bray, W. C. J. Am. Chem. Soc. 1932, $54,4284$.

5. Bray, W. C.; Liebhafsky, H. A. J. Am. Chem. Soc. 1935, 57, 51.

6. Sclar, M.; Riesch, L. C. J. Am. Chem. Soc. 1936, 58, 667.

7. Clarke, J. R. J. Chem. Educ. 1970, 47, 775.

8. Domínguez, A.; Iglesias, E. Langmuir 1998, 14, 2677.

9. Rábai, Gy.; Bazsa, Gy.; Beck, M. T. Int. J. Chem. Kinet. 1981, 13, 1277.
10. Burgos, F. S.; Graciani, M. del M.; Muñoz, E.; Moya, M. L.; Capitán, M. J.; Galán, M.; Hubbard, C. D. J. Sol. Chem. 1988, 17, 653.

11. Raphael, L. In: Chem. Appl. Bromine its Compounds, 1986, chap. 13, p. 369.

12. Lengyel, I.; Nagy, I.; Bazsa, G. J. Phys. Chem. 1989, 93, 2801.

13. Aickin, R. G.; Bayliss, N. S.; Rees, A. L. G. Proc. Roy. Soc. 1939, A169, 234.

14. Lotus 1-2-3, version 5; Lotus Development Co., Cambridge, MA, 1995.

15. Connors, K. A. Chemical Kinetics. The Study of Reaction Rates in Solution. VCH, 1990. p. 36.

16. Loudon, G. M. J. Chem. Educ. 1991, 68, 973.

17. Vauleugenhaghe, C.; Valensi, G.; Pourbaix, M. In: Atlas of Electrochemical Equilibrium in Aqueous Solutions, $2^{\text {nd }}$ ed., Pourbaix, M., ed.; National Association of Corrosion Engineers: Houston, 1974, p. 604.

18. Kamble, D. L.; Nandibewoor, S. T. Int. J. Chem. Kinet. 1996, 28, 673.

19. (a) Laxmi, V. Ph.D. Thesis, Kakatiya University, Warangal, 1978; (b) Reddy, C. S.; Sundaram, E. V. Int. J. Chem. Kinet. 1983, 15, 307; (c) Reddy, C. S.; Sundaram, E. V. Indian J. Chem. 1987, 26A, 118; (d) Reddy, C. S. Z. Phys. Chemie (Leipzig) 1989, 5, 1009.

Received: December 7, 2000 Published on the web: September 20, 2001 